UDC 663.674

DOI https://doi.org/10.32838/2663-5941/2019.6-2/21

\author{
Maletskyi M.V. \\ Oles Honchar Dnipro National University
}

Nalyvaiko A.V.

Oles Honchar Dnipro National University

Kondratjuk N.V.

Oles Honchar Dnipro National University

Suprunenko K.Ye.

Oles Honchar Dnipro National University

Melnikov K.O.

Oles Honchar Dnipro National University

\title{
DEVELOPMENT OF RECIPE FOR LOW-CALOR ICE CREAM
}

The main problem of modern society is the growth of diseases associated with carbohydrate metabolism, which cause overweight, obesity and diabetes of the second type. In this regard, there was a need to create food products with a wide range of useful functions and quite popular among the general public. The technology and recipe for ice cream for dietary purposes using natural sweetener erythritol and sweet extract of stevia leaves have been developed. The advantages of this mixture of natural sweeteners include: thermal stability; chemical resistance over a wide $\mathrm{pH}$ range (2 to 12); biochemical resistance to the action of many species of microorganisms and fungi; long shelf life; good water and fat solubility; introduction into the food mixture at any stage of the technological process; safety with long-term consumption. This mixture is poorly absorbed by the intestinal wall and prevents of caries in the mouth. As a thickener, stabilizer, emulsifier in the ice cream is introduced xanthan and guar gum - a natural useful biopolymers. In the recipe, the fat was completely replaced with the dietary supplement E471 (a mixture of mono- and diglycerides). Also, a positive technological effect was observed after the introduction into the formulation of a mixture of non-starch polysaccharides (xanthan and guar gum in the ratio of 30:70 respectively). In order to increase the dry components of the ice cream produced, the amount of dry skimmed milk whey powder was increased, which made it possible to increase the amount of easily digestible protein in the finished product. The optimal ratio of starch-free polysaccharides, whey concentrations, erythritol sweetener, stevioside sweetener and E471 nutritional supplement was experimentally selected. The organoleptic characteristics of the manufactured product are determined, its nutritional and energy value is calculated.

Key words: ice cream, erythritol, stevioside, diabetes, obesity, functional product, sweeteners.

\section{Formulation of the problem.}

According to World Health Organization reports for 2018, 1.6 million deaths were directly attributable to diabetes in 2016 [1]. Diabetes mortality in 2016 ranked seventh among other causes of death.

Also, in the modern world, the problem of obesity among all age groups of the planet's population remains relevant. According to WHO estimates, in 2016 more than 1.9 billion adults over 18 were overweight. Over 650 million of these were obese. These, unfortunately, are only recorded cases. It is known that obesity and diabetes are related diseases.

The main cause of obesity and overweight is energy imbalance. At the same time, the calorie content of the diet exceeds the energy needs of the body and the consumption of high-calorie foods that contain a large amount of fat is growing [2]. The most common consequences of obesity are diseases of the cardiovascular system and diabetes.

Ice cream is a food product, which is a mass frozen in the process of continuous mixing, containing nutritious, aromatic substances and emulsifiers. Ice cream is popular among people of all ages. The number of consumers of this product reaches $90 \%$ in the summer. Given that ice cream contains a large amount of sugar and fat, this product cannot be considered balanced in nutrient composition.

Prevention and treatment of type 2 diabetes, obesity and overweight is a proper and balanced diet, which includes functional products based on sweeteners and having a high content of non-starch polysaccharides. 
Nowadays, there are known methods of making ice cream with reduced calorie content [3] by replacing sugar with an extract of stevia and ice cream, which is enriched with dietary fiber from Senegalese acacia [4]. However, there are practically no developments in the direction of creating a combined product that contain both a sweetener and polysaccharide fibers. $n$ the analysis of existing information, it also became known that, to reduce calorie content, replacing fat with other components in ice cream is also practically not possible due to deterioration in texture and organoleptic characteristics. Therefore, the aim of the study was to create a product that would not be inferior in terms of organoleptic characteristics to the analogue that Sundae Ice Cream (by SSU 4733:2007) was chosen. It also would have low calorie content and high biological value.

\section{Analysis of recent research and publications.}

Various programs and methods are offered to prevent the development of obesity and diabetes [5;6]. It also creates products with functional properties.

The authors [7] describe ways to reduce the incidence of diabetes and obesity by reducing the amount of sugar and fat consumed. It is intended to the rejection of most desserts as a source of a large amount of sucrose and fat. This greatly reduces the range of desserts allowed for consumption, including ice cream. However, there is other confirmed information [8] that the deficiency of sweet foods in people's diets increases the risk of the negative effects of various stresses, since the body produces little serotonin and endorphin - hormones of calmness and joy.

Today, there are a number of technologies in which sweeteners, such as a sweet extract from stevia leaves and erythritol, are used to give products a sweet taste.

Erythritol (E968) - a polyhydric alcohol, belongs to the class of polyols. It is non-nutritive $\left(0.3 \mathrm{kcal} / \mathrm{g}^{-1}\right)$. It has a sweetness of 0.7 with respect to sucrose. It contained in melon, pear, grapes, mushrooms and algae. It is well absorbed in the intestine and excreted in the urine with virtually no changes. Widely used in the technology of chocolate, bakery products, dairy products. Erythritol is a product of microbial transformation of low molecular weight carbohydrates. Numerous studies have proven the safety of erythritol [9].

"Sweet Stevia Leaf Extract" is a natural sweetener made from stevia. At its core is terpenoid-glycoside stevioside (E960). Has sweetness 200-300 times higher than the sweetness of sugar [10].

Formulation of the problem. Sweet cold dessert (ice cream) is a popular food product among all age groups of people. Especially its popularity increases in the hot season. The disadvantage of existing types of ice-cream is an imbalance in nutrient composition - a high content of sugar and fat. According to SSU 4733, the fat content in ice cream can reach $20.0 \%$, the total sugar content is not more than $14.0 \%$. Also, according to $\mathrm{SSU}$, the manufacture of diabetic ice cream is allowed, where sugar is replaced with sweeteners - sorbitol, xylitol, acesulfame. The content of dietary fiber in ice cream is regulated by the technological standards of manufacturers of food additives [11].

In connection with the above information, it became necessary to develop an ice cream technology that has high organoleptic characteristics, contains dietary fiber and does not contain sucrose. In addition, it is very important to find solutions in the direction of reducing the fat content or replacing it with more useful components that do not change the texture and general perception of the product by the consumer. A product with the given characteristic would satisfy the needs of people with impaired carbohydrate metabolism, diabetes, obesity, overweight, adhering to a diet, etc. At the same time, they could enjoy the taste of classic ice cream.

Statement of the main research material. The sundae ice cream [11] was taken as an analogue. The physicochemical parameters of which are shown in Table 1.

Table 1.

Physicochemical indicators of sundae ice cream

\begin{tabular}{|c|c|}
\hline Name of indicator & Mass fraction, $\%$ \\
\hline Total fat & $13,0 \ldots 20,0$ \\
\hline Total sugar & 14,0 \\
\hline Solid matters & 42,0 \\
\hline
\end{tabular}

The milk defatted whey was taken for the basis for a product that was developed. Whey was preliminarily flooded with water at $t^{\circ} \mathrm{C}=20 \ldots 25^{\circ} \mathrm{C}$ for protein swelling. Xanthan and guar gums were used to give a creamy consistency. In the table. 2 shows the results of tasting tests of prototypes that are similar in consistency to the product-analogue of sundae ice-cream.

Table 2

The results of tasting tests prototypes

\begin{tabular}{|c|c|c|c|}
\hline Sample number & $\begin{array}{c}\text { Mass } \\
\text { fraction of } \\
\text { xanthan } \\
\text { gum, \% }\end{array}$ & $\begin{array}{c}\text { Mass } \\
\text { fraction of } \\
\text { guar gum, } \\
\text { \%o }\end{array}$ & $\begin{array}{c}\text { Consis- } \\
\text { tency } \\
\text { score, } \\
\text { points }\end{array}$ \\
\hline Sample № 1 & 100 & - & 2 \\
\hline Sample № 2 & - & 100 & 3 \\
\hline Sample № 3 & 50 & 50 & 4 \\
\hline Sample № 4 & 30 & 70 & 5 \\
\hline
\end{tabular}


Milk fat, it was decided to replace the food supplement E471. It is a mixture of mono- and diglycerides. This prescription component plays the role of an emulsifier in the mixture and has useful functions for the body, since it is similar in structure to partially digested fat. The sweeteners erythritol and "Sweet extract from stevia leaves" were introduced as a mixture in the ratio of $96.5: 3.5$, respectively.

The results of the organoleptic evaluation of the samples are given below.

1. Sample № 1.1 with a rate of application of $0,5 \mathrm{~g}$ of dry xanthan gum per $100 \mathrm{~g}$ of the finished product had a pronounced mucous consistency and a watery taste.

2. Sample № 1.2 with a rate of application $0,5 \mathrm{~g}$ of dry guar gum per $100 \mathrm{~g}$ of the finished product had a liquid consistency.

3. Sample № 1.3 with a rate of application the mix of $0,5 \mathrm{~g}$ guar gum and $0,5 \mathrm{~g}$ of dry xanthan gum per $100 \mathrm{~g}$ of the finished product had lumpy consistency.

4. Sample № 1.4 with a rate of application the mix of $0,3 \mathrm{~g}$ of dry xanthan gum and $0,7 \mathrm{~g}$ of dry guar gum per $100 \mathrm{~g}$ of the finished product (further mixture 3:7) had a pleasant, delicate creamy consistency.

These results allowed us to simulate the recipe for low-calorie ice cream (table 3).

Table 3

Optimized low-calorie ice cream recipe

\begin{tabular}{|c|c|c|}
\hline Ingredient & Sample № 2.1 & Sample № 2.2 \\
\hline Dry milk whey & 29.41 & 29.41 \\
\hline Erythritol & 10.9 & 10.9 \\
\hline Egg powder & 0.9 & 0.9 \\
\hline $\begin{array}{c}\text { Stevia Leaf Sweet } \\
\text { Extract }\end{array}$ & 0.39 & 0.39 \\
\hline Mixture 3:7 & 1 & 1 \\
\hline E471 & - & 0,25 \\
\hline Fragrance "Vanilla" & $0.05 \ldots 0.07$ & $0.05 \ldots 0.07$ \\
\hline $\begin{array}{c}\text { Fragrance "Cream } \\
\text { Plus" }\end{array}$ & 0.1 & 0.1 \\
\hline Water & 71.86 & 71.86 \\
\hline
\end{tabular}

The results of organoleptic evaluation of samples and analogue are presented in the figure 1.

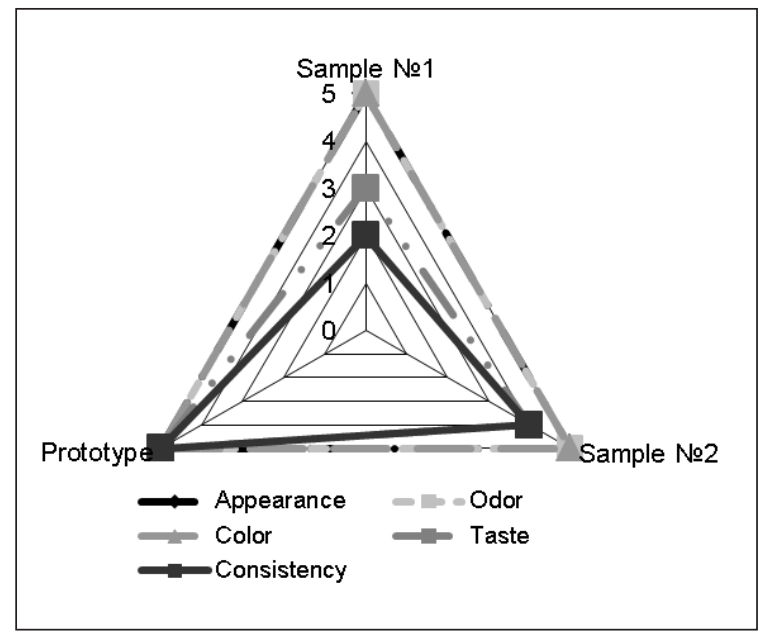

Fig. 1. Organoleptic sample profiles

A nutritional value was calculated for these samples. The results are shown in table 4 .

From the data given in table. Figure 4 shows that the studied samples contain more protein, the fat content is almost 15 times lower due to the introduction of food additive E471 and a mixture of dietary fiber.

Due to the addition of sweeteners, only milk sugar (lactose) remained in the test samples, which, according to DSTU 4733, is not taken into account in the column as "Total sugar" and is not standardized. As a result, you can see that the calorie content of the developed product has decreased by half.

Conclusions. In this work was presented the technology of a cold dessert (ice cream) with functional properties. Sugar substitutes "Sweet extract from stevia leaves" and erythritol, as well as a mixture of guar and xanthan gums were taken as functional components. A dried whey, fatty acid monoglycerides (food supplement E471), and natural flavors were used for the production of ice cream. As a result, was received a dietary product with a reduced fat content of almost 15 times, an increased protein content and a complete lack of sucrose. The caloric content of this product was almost halved. At the same time, the developed samples have a high organoleptic rating, which is not inferior to the product-analogue "Sundae Ice-Cream". The product with the given characteristic can be recommended for people with impaired carbohydrate metabolism, diabetes, obesity, overweight, adhering to a diet, etc.

Table 4

Nutritional value of analogue product and test samples

\begin{tabular}{|c|c|c|c|c|c|c|}
\hline Name & Proteins, $\mathbf{g}$ & Fat, $\mathbf{g}$ & Carbohydrates *, g & Total sugar, \% & Food fiber, g & Calories, kcal \\
\hline Analogue product & 3.7 & 15 & 36.3 & 14 & 0 & 232 \\
\hline Sample № 2.1 & 4.1 & 0.3 & 21.3 & 0 & 1 & 103.4 \\
\hline Sample № 2.2 & 4.1 & 0.3 & 21.3 & 0 & 1 & 103.4 \\
\hline
\end{tabular}

* - including whey lactose. 


\section{References:}

1. Диабет. Всемирная организация здравоохранения: веб-сайт. URL : https://www.who.int/ru/news-room/ fact-sheets/detail/diabetes (дата обращения: 9.11.2019).

2. Ожирение и избыточный вес. Всемирная организация здравоохранения: веб-сайт. URL : https://www. who.int/ru/news-room/fact-sheets/detail/obesity-and-overweight (дата обращения: 9.11.2019).

3. Спосіб виробництва дієтичного морозива: пат. 10534 Україна: МПК А23С 9/00.№ a1996 10534 заявл. 14.09.1996; опубл. 25.12.1996

4. Морозиво ацидофільне з підвищеною біологічною цінністю: пат. 27779 Україна МПК A23G 9/00. № a2007 27779 заявл. 07.07.2007; опубл. 12.11.2007.

5. Глобальный план действий по профилактике по профилактике неинфекционных заболеваний и борьбе с ними на 2013-2020 гг.: Всемирная организация здравоохранения.

6. Ларина В. Н. Рекомендации по профилактике сердечно-сосудистых заболеваний в клинической практике. EuroPrevent Meeting 2016: материалы EuroPrevent Meeting 2016, 5-7 мая 2016. Стамбул, Турция: European Heart Journal (2016) 37.2315-2381, 2016.

7. Marcio Carocho, Patricia Morales, Isabel C.F.R. Ferreira Sweeteners as food additives in the XXI century: A review of what is known, and what is to come. Food and Chemical Toxicology. 2017. №107. C. 302-317.

8. Polyvanov Y.A., Maletskiy M.V., Murzenko Y.S. Justofocation and development of chocolate technology with stevioside to reduce the risk of disesse diabetes type 2 // The Third International scientific congress of scientists of Europell. Proceedings of the III International Scientific Forum of Scientists "East-West" (January 11, 2019). Premier Publishing s.r.o. Vienna. 2019. P. 681-684.

9. Polyvanov Ye.A., Murzenko Ye.S. Heritriyol, steviozide and uronatic polysaccharides the technology of production of sweet sources for diabetes prophylax (DM 2) and obesity // Published and printed in Germany by ORT Publishing (Germany) in association with the Center For Scientific Research - Solutionll (Ukraine), December 28, 2018. - P.334-339.

10. URL : https://stevia.in.ua/.

11. ДСТУ 4733:2007. Мороженое молочное, сливочное, пломбир. Общие технические условия. [Действительный от 01.01.2008]. Киев, 2007. 36 с. (Информация и документация).

\section{Малецький М.В., Наливайко А.В., Кондратюк Н.В., Супруненко К.Є., Мельников К.О. РОЗРОБЛЕННЯ РЕЦЕПТУРИ НИЗЬКОКАЛОРІЙНОГО МОРОЗИВА}

Основна проблема сучасного суспільства - зростання захворювань, пов'язаних із порушенням обміну вуглеводів, щео спричиняють зайву вагу, ожиріння та діабет другого типу. У зв'язку із иим виникла необхідність у створенні харчових продуктів із широким спектром корисних функцій $і$ досить популярних серед широкого населення. Розроблена технологія та рецептура дієтичного морозива з використанням натурального підсолоджувача еритритолу та солодкого екстракту з листя стевії. У рецептурі жир повністю замінили харчовою добавкою Е471 (суміш моно- та диглічеридів). Також позитивний технологічний ефект був відмічений після введення в рецептуру суміші некрохмальних полісахаридів (ксантану та гуарової камеді у співвідношенні 30:70 відповідно). Із метою збільшення сухих компонентів було збільшено кількість сухої знежиреної молочної сироватки. Це дозволило збільшити кількість легкозасвоюваного білка в готовому продукті. Експериментально було обрано оптимальне співвідношення безкрохмальних полісахаридів, концентраиї молочної сироватки, підсолоджувача еритритолу, підсолоджувача стевіозиду та харчової добавки Е471. Також було визначено органолептичні характеристики розробленого продукту, обчислена його харчова та енергетична цінність.

Ключові слова: морозиво, еритритол, стевіозид, діабет, ожиріння, функиіональний продукт, підсолоджувачі. 